\title{
Pembuatan Aplikasi Augmented Reality Sebagai Media Pengenalan Alat Musik Gamelan Jawa Berbasis Android
}

\author{
Ahmad Triaji \\ Politeknik Negeri Media Kreatif, Jl Srengseng Sawah Jagakarsa Jakarta Selatan, 12640
}

\begin{tabular}{l} 
INFORMASI ARTIKEL \\
\hline $\begin{array}{l}\text { Sejarah Artikel: } \\
\text { Diterima Redaksi: } 03 \text { November } 2021 \\
\text { Revisi Akhir: } 01 \text { Desember } 2021 \\
\text { Diterbitkan Online: } 05 \\
\text { Desember } 2021\end{array}$ \\
KATA KUNCI \\
\hline Gamelan, Musik Tradisional, Augmented \\
Reality \\
KORESPONDENSI \\
\hline
\end{tabular}

Email: 18810162@polimedia.ac.id

\section{ABSTRACT}

Di era sekarang sudah sangat jarang masyarakat khususnya pemuda yang ingin menyalurkan hobinya kedalam seni pertunjukan musik khususnya alat musiknya itu sendiri, termasuk alat musik gamelan ini merupakan titipan leluhur kita untuk anak cucu cicit kita, Bukan sekedar warisan leluhur untuk kita saja. Dengan adanya masalah tersebut maka akan dibuatkan sebuah Aplikasi Media pengenalan Augmented Reality dalam membantu pengenalan alat musik seni Gamelan ini. Data yang diperlukan melalui tahapan observasi, interview narasumber dan studi Pustaka. Setelah memperoleh data yang dibutuhkan akan dilakukan pembuatan desain objek 3D Gamelan, Video pertunjukan Gamelan. Hasil akhirnya berupa booklet yang berisikan informasi dan gambar terkait gamelan. Semoga Pembuatan aplikasi ini dapat membantu meningkatkan pemahaman dan partisipasi dalam belajar mengenai seni musik gamelan dan Aplikasi ini dapat dijadikan sebagai media untuk memperkenalkan sekaligus melestarikan budaya bangsa.

DOI: $10.46961 /$ jommit.v5i2.418

\section{PENDAHULUAN}

Indonesia merupakan negara yang kaya akan kebudayaannya, kebudayaan yang telah dibentuk masyarakat dan menjadi identitas daerah, perlu dilestarikan agar tetap ada meskipun terjadi perubahan zaman. Salah satu kebudayaan yang eksistensinya terancam oleh perubahan zaman adalah seni musik tradisional. Gamelan merupakan salah satu alat musik tradisional yang biasa menjadi pengiring kesenian wayangan dan karawitan. Gamelan merupakan produk budaya yang berasal dari jawa. kesenian adalah unsur budaya yang kedua nya saling terkait dengan yang lainnya, dimana masyarakat yang mempunyai kebudayaan akan lahir kesenian-kesenian yang muncul, dan gamelan merupakan hasil dari kebudayaan jawa. Gamelan pada saat ini tidak hanya dikenal di Indonesia saja, melainkan sudah berkembang di berbagai negara diantaranya di Amerika Serikat, Jepang, Inggris, dan Kanada (Kompas, 2019). Karena itu sungguh ironis jika Indonesia khususnya jawa sebagai pewaris langsung tidak peduli bahkan menganggapnya kuno. Jika ini dibiarkan begitu saja, gamelan yang merupakan kebudayaan jawa akan hilang eksistensinya ditanah sendiri, mengingat negara lain begitu gencar-gencarnya mempelajari gamelan jawa, sudah waktunya untuk peduli budaya dan kesenian bangsa khususnya gamelan.

Dan juga ada Penurunan minat masyarakat terhadap seni musik gamelan, oleh beberapa jurnal yakni saat ini kesenian gamelan berangsur mulai tersingkir. Hal tersebut dipengaruhi banyak faktor yang terjadi di dalam lapisan masyarakat, seperti halnya banyak kesenian dari luar yang sangat persuasif dan lebih diminati. Akhirnya mereka lebih berminat untuk mengikuti seni modern yang sedang marak digemari banyak orang. Adanya anggapan bahwa kesenian gamelan dianggap sudah kuno sehingga banyak anak muda mengabaikannya begitu saja (Noor Hidayat Iswara, "Dinamika Kesenian Gamelan Pada fungsi dan pelestarian kesenian gamelan dalam sanggar budaya singahasari di kecamatan Singosari, Kabupaten Malang, Jawa Timur"). Budaya barat dan modernisasi merupakan konsumsi sehari-hari anak-anak muda. Akibatnya kesenian dan budaya sendiri dianggap tidak nge-trend dan terkesan kuno, sehingga generasi penerus tidak mau menggelutinya bahkan mereka sudah tidak lagi mengenal budaya sendiri. Hal ini terbukti dengan semakin menurunnya minat generasi muda khususnya di Jawa untuk 
melihat pagelaran kesenian Jawa, bukan tidak berminat terhadap kesenian tradisional tetapi bentuk kemasan yang harus disesuaikan dengan kondisi sekarang sehingga tidak membosankan (Kompas.com "Anak Muda Ogah Melirik Seni Tradisional”). Dikutip dari hasil wawancara penulis dengan salah satu pelaku musisi gamelan Agung Bekti Wicaksono pelatih di Sanggar Samurti Andaru Laras, "Bahwa dilihat secara luas praserta dari sekolah itu penting karena ini adalah instansi atau lembaga untuk memperkenalkan budaya tersebut sejak dini agar terbentuknya pondasi kecintaan terhadap gamelan, kedua dari lingkungan pembentuk/bertumbuh dan pemerintah harus membatasi budaya yang masuk dari luar kalau tidak dibatasi bisa jadi anak di Indonesia tidak tahu tentang budaya nya sendiri”. Dari beberapa kutipan tentang penurunan minat masyarakat terhadap gamelan penulis bisa menyimpulkan bahwa sebab kebanyakan faktor penurunan minat disebabkan oleh budaya dari luar yang datang sehingga minat masyarakat menganggap seni gamelan ini kuno.

Bentuk media pembelajaran pemanfaatan media pendidikan menggunakan Augmented Reality dapat merangsang pola pikir peserta didik dalam berpikiran kritis terhadap sesuatu masalah dan kejadian yang ada pada keseharian, karena sifat dari media pendidikan adalah membantu peserta didik dalam proses pembelajaran dengan ada atau tidak adanya pendidik dalam proses pendidikan, sehingga pemanfaatan media pendidikan dengan Augmented Reality dapat secara langsung memberikan pembelajaran dimanapun dan kapanpun peserta didik ingin melaksanakan proses pembelajaran. Media pembelajaran AR dapat memvisualisasikan konsep abstrak untuk pemahaman dan struktur suatu model objek memungkinkan AR sebagai media yang lebih efektif sesuai dengan tujuan dari media pembelajaran. Pemanfaatan media pembelajaran dengan AR sangat bermanfaat dalam meningkatkan proses belajar serta minat peserta didik dalam belajar karena dalam AR sendiri memiliki aspek-aspek hiburan yang dapat meningkatkan minat peserta didik dalam belajar dan bermain serta memproyeksikannya secara nyata dan melibatkan interaksi seluruh panca indera peserta didik dengan teknologi AR ini. Hal ini disebabkan karena AR memiliki karakteristik serta fungsi yang hampir sama dengan media pembelajaran yaitu berfungsi menyampaikan informasi antara penerima dan pengirim atau pendidik dengan peserta didik, dapat memperjelas penyampaian informasi yang diberikan pendidik dan peserta didik dalam proses pembelajaran, dapat memberikan rangsangan motivasi serta ketertarikan dalam pembelajaran (Ilmawan Mustaqim "Pemanfaatan Augmented Reality Sebagai Media Pembelajaran” 2016).

\section{TINJAUAN PUSTAKA}

\subsection{Augmented Reality}

Augmented Reality merupakan sebuah terobosan dan inovasi bidang multimedia dan image processing yang sedang berkembang. Teknologi ini dapat mengangkat sebuah media yang sebelumnya datar atau bisa disebut dua dimensi, seolah-olah menjadi nyata, bersatu dengan lingkungan sekitarnya (Panduan Mudah Membuat Augmented Reality, Budi Arifitama 2017). Sedangkan menurut Jorge dan Pena, Augmented Reality adalah proses menggabungkan data virtual dengan data dunia nyata dapat memberikan pengguna untuk mengakses konten multimedia yang kaya serta bersifat relevan secara kontekstual dan dapat dengan mudah digunakan. Benda-benda maya menampilkan informasi yang tidak dapat diterima oleh pengguna dengan inderanya sendiri. Hal ini membuat Augmented Reality sesuai sebagai alat untuk membantu persepsi dan interaksi penggunanya dengan dunia nyata. Informasi yang ditampilkan oleh benda maya membantu pengguna melaksanakan kegiatan-kegiatan dalam dunia nyata.

Menurut Milgram, Augmented Reality memungkinkan perspektif diperkaya dengan menampilkan objek virtual pada dunia nyata dengan cara mengajak penonton bahwa objek virtual adalah bagian dari lingkingan nyata. Augmented Reality merupakan crossover antara dunia nyata dan virtual.

Ronald T. Azuma mendefinisikan Augmented Reality sebagai penggabungan benda-benda nyata dan maya di lingkungan nyata, berjalan secara interaktif dalam waktu nyata (real time), dan terdapat integrasi antar benda dalam tiga dimensi, yaitu benda maya terintegrasi dengan teknolgi tampilan yang sesuai, interaktivitas dimungkinkan melalui perangkat-perangkat input tertentu. Bidang-bidang yang menerapkan terknologi Augmented Reality adalah:

1. Bidang pemasaran digunakan untuk mempromosikan barang atau jasa dengan brosur virtual yang memberikan informasi lengkap secara tiga dimensi sehingga pelanggan dapat mengetahui secara jelas mengenai barang atau jasa yang ditawarkan.

2. Bidang Pendidikan digunakan untuk proses belajar mengajar yang memberikan efek-efek yang dapat mengubah gambar animasi tentang cuaca tersebut.

3. Bidang desain teknologi digunakan untuk menampilkan hasil desain mereka secara nyata terhadap klien.

\subsubsection{Metode Penggunaan Augmented Reality}

Secara garis besar, Augmented Reality ini terbagi menjadi 2 metode, yaitu Marker Based Tracking dan juga Markerless Augmented Reality. Berikut ini adalah metode yang digunakan atau dikembanhkan pada teknologi Augmented Reality adalah:

\section{a. Marker Augmented Reality}

Marker biasanya merupakan ilustrasi hitam dan putih persegi dengan batas hitam tebal dan latar belakang putih. Komputer akan mengenali posisi dan orientasi marker dan menciptakan dunia virtual 3D yaitu titik $(0,0,0)$ dan 3 sumbu yaitu X,Y,dan Z. Marker Based Tracking ini sudah lama dikembangkan sejak 1980-an dan pada awal 1990-an mulai dikembangkan untuk penggunaan Augmented Reality.

\section{b. Markerless Augmented Reality}

Metode ini pengguna tidak perlu lagi menggunakan sebuah marker untuk menampilkan elemen-elemen digital. Saat ini Markerless Augmented Realit 
banyak dikembangkan oleh perusahaan-perusahaan besar, mereka telah membuat aplikasi AR dengan berbagai macam teknik Markerless Tracking sebagai teknologi andalan mereka, seperti Face Tracking, 3D Object Tracking, Motion Tracking dan GPS Based Tracking.

\subsection{Media Pembelajaran}

Media pembelajaran merupakan suatu alat perantara antara pendidik dengan peserta didik dalam pembelajaran yang mampu menghubungkan, memberi informasi dan menyalurkan pesan sehingga tercipta proses pembelajaran efektif dan efisien. Media pembelajaran mengakibatkan terjadinya sebuah komunikasi antara pendidik dan peserta didik dalam proses pembelajaran. Apabila dalam proses pembelajaran tidak menggunakan media maka tidak akan terjadi proses pembelajaran.

Kustandi dan Sutjipto (2013:19), kedudukan media dalam sistem pembelajaran adalah sebagai alat bantu, alat penyalur pesan, alat penguatan, dan wakil guru dalam menyampaikan informasi secara teliti, jelas, dan menarik. Menurut Daryanto (2011:6) media pembelajaran menempati posisi yang sangat penting dalam pembelajaran. Media pembelajaran mengakibatkan terjadinya sebuah komunikasi antara pendidik dan peserta didik dalam proses pembelajaran. Apabila dalam proses pembelajaran tidak menggunakan media maka tidak akan terjadi proses pembelajaran. Hal ini disebabkan komunikasi antara pendidik dan peserta didik berlangsung secara tidak optimal. Media menjadi perantara untuk menciptakan komunikasi, bertugas untuk mempermudah pendidik dan peserta didik untuk berkomunikasi, sehingga akan terjadi proses belajar mengajar yang mengakibatkan peserta didik akan memahami hal yang diberikan pendidik.

\subsection{Gamelan Jawa}

Indonesia merupakan negara yang besar dan kaya dengan budaya berbagai tradisi musik, salah satu musik khas Indonesia, yakni gamelan Jawa. Gamelan berasal dari kata nggamel (dalam bahasa jawa)/gamel yang berarti memukul/menabuh, diikuti akhiran "an" yang menjadikannya sebagai kata benda (Ferdiansah). Gamelan Jawa merupakan alat musik yang muncul dari sejarah kebudayaan Jawa yang di dalam perkembangannya selalu dipakai mengiringi pagelaran wayang maupun pengisi suatu pagelaran adat istiadat orang Jawa (Prasetyo). Mengutip pernyataan Fatmawati (2017) gamelan jawa adalah ensambel musik yang biasanya menonjolkan metalofon, gambang, gendang, dan gong. Musik yang tercipta pada gamelan berasal dari perpaduan alat musik yang ada di dalamnya yang kemudian disebut musik gamelan jawa atau dalam Bahasa Jawa disebut karawitan.

Berdasarkan pada sumber bunyinya, gamelan jawa terbagi menjadi empat jenis. Masing-masing jenis memiliki instrumen dengan karakter suara yang berbeda-beda

\subsection{Aplikasi Berbasis Andorid}

Menurut Nazaruddin, Android merupakan sistem operasi untuk telepon seluler yang berbasis Linux. Android menyediakan platform yang terbuka untuk para pengembang atau Developer untuk membuat aplikasi mereka sendiri agar dapat digunakan bermacam peranti bergerak. Android umum digunakan di Smartphone dan juga di tablet PC. Fungsinya sama seperti sistem operasi Symbian di Nokia, iOS di Apple dan BlackBerry OS. (2012: 1)

\section{KONSEP PERANCANGAN}

\subsection{Data/Objek Penulisan}

Penulis menggunakan data objek untuk penulisan melalui Sanggar SALgamelan (Samurti Andaru Laras) atau Komunitas gamelan anak muda Jabodetabek, yang bergerak pada kesenian budaya Indonesia yaitu Karawitan Gamelan Jawa yang bergaya Solo atau Jogja. Sanggar ini berlokasi di Ibukota tepatnya di beberapa lokasi yang menyewakan set alat gamelan di wilayah Jakarta Selatan.

SALgamelan ini Awal mulanya dari bergabungnya salah satu pendiri komunitas ini dikelas gamelan ditempat program Bahasa Inggris di daerah Jakarta selatan dengan karyawan setempat sekitar tahun 2013. Karena hanya ada 1 anak muda yang ikut latihan diantara peserta bapak-bapak dan ibu-ibu, Putri Nurjana dan Rasyid (Pendiri Sanggar/Komunitas) mengajak anak-anak muda yang lain disalah satu forum Indonesia, terkumpulah sekitar 16 anak muda yang berstatus mahasiswa dan yang sudah bekerja, kelas perdana di LIA Pengadegan, Jakarta dimulai pada tahun 2014 dengan nama Jakarta Gamelan Community (JGC) setelah itu di tahun yang sama berganti menjadi Samurti Andaru Laras/SALgamelan. Untuk sekarang SALgamelan sendiri rutin mengadakan latihan setiap minggunya.

Berdasarkan anggota yang tergabung di Whatsapp grup per Mei 2021 ada 29 orang, kalau yang sudah pernah pastinya pengurus tidak menghitung secara pasti. Untuk usia peserta yang belajar di SALgamelan sendiri ada yang dari 17 tahun sampai 40 tahunan, mereka memasang target di usia tersebut karena ingin melestarikan kebudayaan ini khusus ke generasi muda. Dan untuk mengenalkan Gamelan ini kepada peserta baru awalnya memperkenalkan alatnya jika sudah ditempatkan sesuai alat yang dimainkan langsung di ajari oleh pelatih cara menabuh dasar sesuai dengan alat yang dipegang dan praktek mulai dari gending atau lagu jawa klasik dengan not sederhana.

\subsection{Perancangan Sistem}

UML (Unified Modeling Language) adalah bahasa pemodelan untuk sistem atau perangkat lunak yang berparadigma "berorientasi objek" Tujuan Penggunaan UML adalah:

1. Memberikan Bahasa pemodelan yang bebas dari berbagai Bahasa pemograman dan proses rekayasa. 
2. Menyatukan praktek-praktek terbaik yang terdapat dalam pemodelan.

3. Memberikan model yang siap pakai, bahasa pemodelan visual yang ekspresif untuk mengembangkan dan saling menukar model dengan mudah dan dimengerti secara umum.

UML bisa juga berfungsi sebagai sebuah (blueprint) cetak biru karena sangat lengkap dan detail. Dengan cetak biru ini maka akan bias diketahui informasi secara detail tentang coding program atau bahkan membaca program dan menginterpretasikan kembali ke dalam bentuk diagram (reserve enginering).

\subsubsection{Use Case Diagram}

Sebuah Use Case Diagram menyatakan melalui visualisasi interaksi yang terjadi antara pengguna (aktor) dengan sistem diagram ini bisa menjadi gambaran yang bagus untuk menjelaskan konteks dari sebuah sistem sehingga terlihat jelas batasan dari sistem
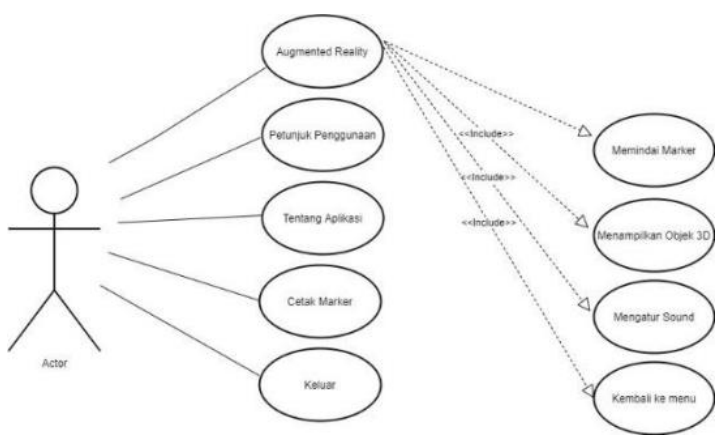

Gambar 3.1 Use Case Diagram Aplikasi AR Gamelan jawa (Sumber : karya penulis)

\subsubsection{Activity Diagram}

Activity Diagram menggambarkan work flow (aliran kerja) atau aktivitas dari sebuah sistem atau proses bisnis atau menu yang ada pada perangkat lunak. Diagram ini memperlihatkan aliran dari suatu aktivitas lainnya dalam suatu sistem. Activity Diagram dapat menunjukkan bentuk kumpulan aksi-aksi dan dapat memperlihatkan bagaimana masing-masing aksi tersebut dimulai hingga berakhir.

\section{a. Activity Diagram AR Camera}

Activity Diagram ini menggambarkan sebuah aktivitas ketika pengguna atau actor menekantombol $A R$ Camera kemudian sistem akan mengaktifkan halaman AR Camera

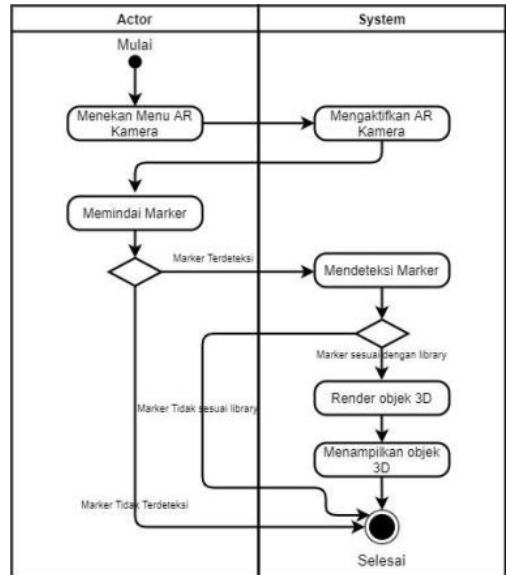

Gambar 3.2 Activity Diagram Ar Camera (Sumber : karya penulis)

b. Activity Diagram Petunjuk Penggunaan

Activity Diagram ini menggambarkan sebuah aktivitas ketika pengguna atau aktor menekan tombol petunjuk penggunaan, kemudian sistem akan menampilkan halaman petunjuk penggunaan.

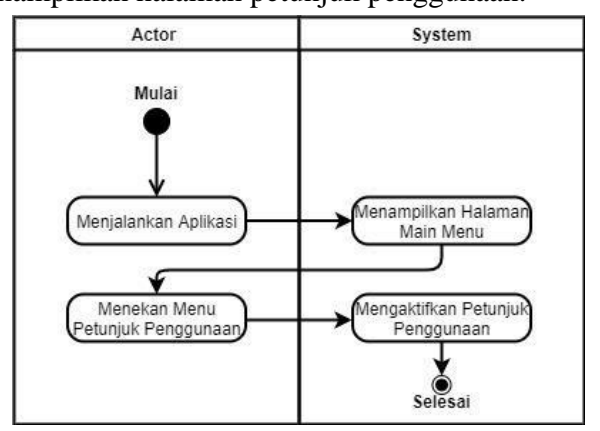

Gambar 3.3 Activity Diagram Petunjuk Penggunaan

(Sumber : karya penulis)

c. Activity Diagram Tentang Aplikasi

Activity Diagram ini menggambarkan sebuah aktivitas Ketika pengguna atau aktor menekan tombol tentang aplikasi, kemudian sistem akan menampilkan halaman tentang aplikasi.

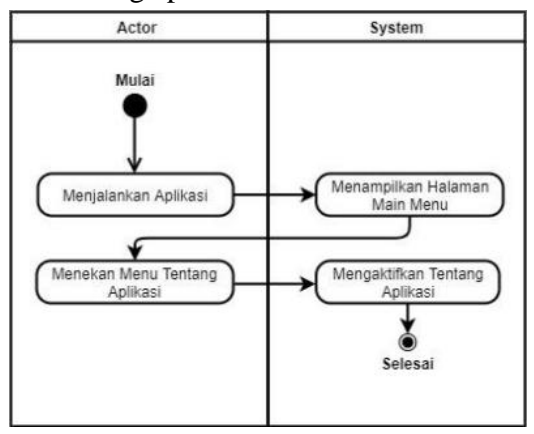

Gambar 3.4 Activity Diagram Tentang Aplikasi (Sumber : karya penulis) 
d. Activity Diagram Cetak Marker

Activity Diagram ini menggambarkan sebuah aktivitas ketika pengguna atau actor menekantombol cetak marker, kemudian sistem akan mengarahkan penggunaa pada link untuk mendownload marker digital.

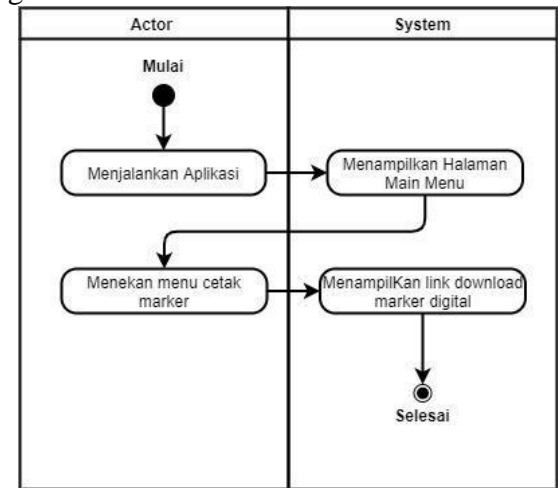

Gambar 3.4 Activity Diagram Cetak Marker

(Sumber : karya penulis)

e. Activity Diagram Keluar Aplikasi

Activity Diagram ini menggambarkan sebuah aktivitas ketika pengguna atau aktor menekan tombol keluar, kemudian sistem akan menampilkan pop up iya atau tidak.

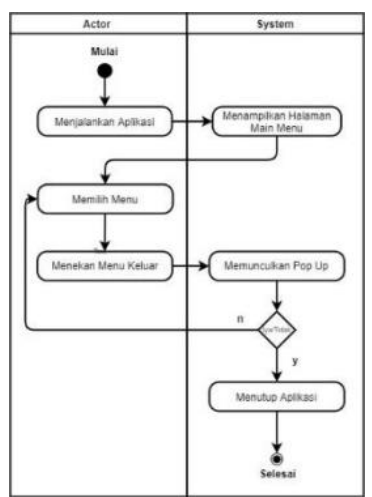

Gambar 3.4 Activity Diagram Keluar Aplikasi

(Sumber : karya penulis)

\subsubsection{Sequance Diagram}

Sequence Diagram adalah diagram yang menggambarkan kolaborasi dinamis antara sejumlah objek. Berikut merupakan sequence diagram pada objek scan marker.

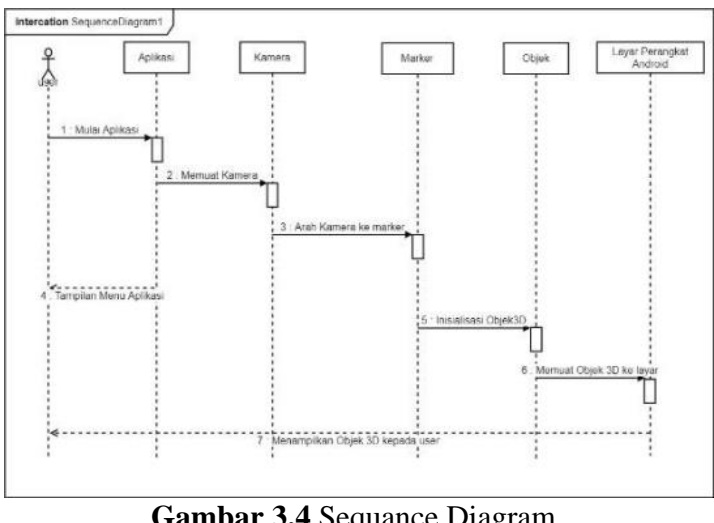

Gambar 3.4 Sequance Diagram

(Sumber : karya penulis)

\section{HASIL DAN PEMBAHASAN}

\subsection{Tampilan Halaman Splash Screen}

Splash Screen adalah tampilan awal saat aplikasi AR Gamelan dijalankan ini juga merupakan tampilan sebelum masuk ke scene main menu, Gambar 4.2 menunjukan tampilan dari splash screen.

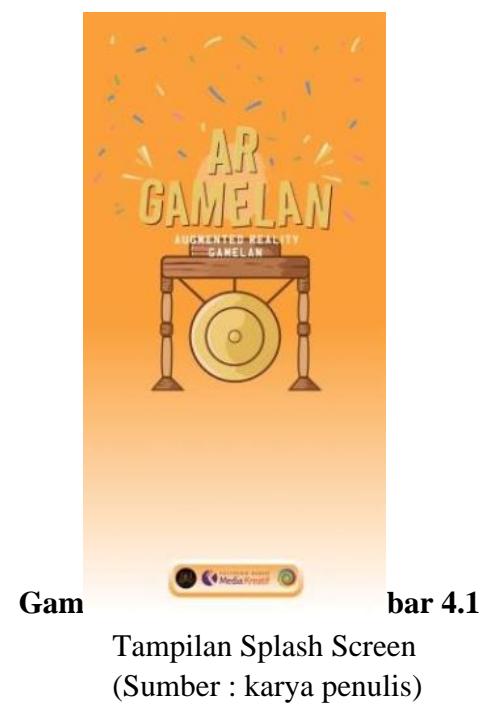

\subsection{Tampilan Halaman Main Menu}

Pada halaman ini pengguna dapat melihat lima pilihan fitur menu lai nnya untuk memasuki halaman lainya yang bisa digunakan. Lima menu tersebut ada AR Camera, petunjuk penggunaan, tentang aplikasi, cetak marker, dan keluar. Di menu utama ini juga terdapat backsound musik intrumen dari gamelan, jika ingin menon-aktifkannya terdapat button sound pada atas kiri layar tampilan. 


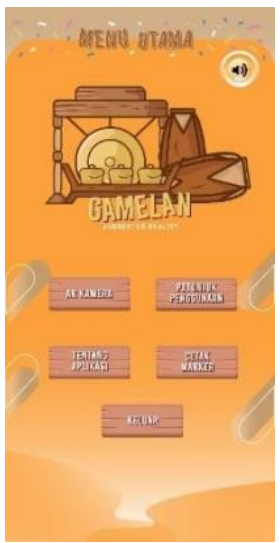

Gambar 4.2 Tampilan Main Menu

(Sumber : karya penulis)

\subsection{Tampilan Halaman AR Camera}

Halaman AR Camera adalah tampilan yang berisi objek 3D yang telah dibuat. Objek 3D akan tampil ketika tombol AR Camera pada main menu ditekan Halaman AR Camera akan menjalankan kamera AR yang jika diarahkan pada marker objek alat music Gamelan akan menampilkan objek 3D alat musik Gamelan diantaranya kendang, saron, gong, gambang, bonang, dan kenong.

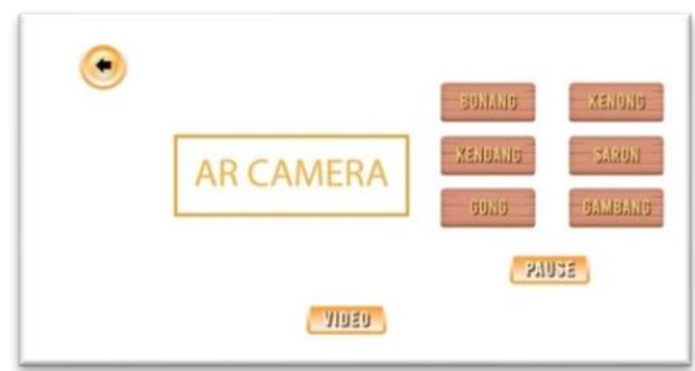

Gambar 4.3 Tampilan Halaman AR Camera (Sumber : Karya Penulis)

\subsection{Tampilan Petunjuk Penggunaan}

Pada Tampilan Petunjuk penggunaan menampilkan informasi atau bantuan mengenai cara penggunaan aplikasi dalam menggunakan fitur augmented reality.

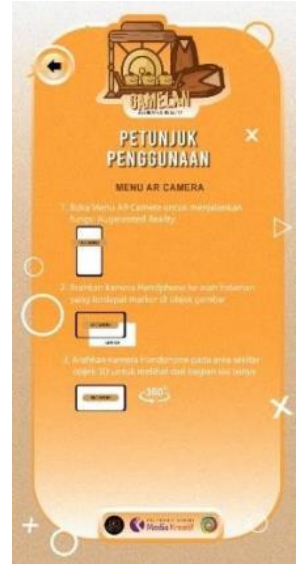

Gambar 4.4 Tampilan Halaman Petunjuk Penggunaan (Sumber : Karya Penulis)

\subsection{Tampilan Tentang Aplikasi}

Halaman tentang aplikasi menampilkan informasi deskripsi singkat aplikasi dan pembuat dalam aplikasi ini.

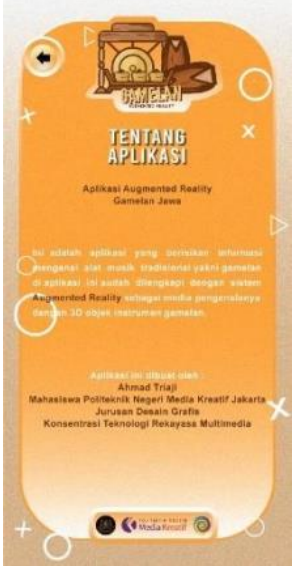

Gambar 4.5 Tampilan Halaman Tentang Aplikasi (Sumber : karya penulis)

\subsection{Tampilan Halaman Keluar Aplikasi}

Halaman Keluar Aplikasi merupakan tampilan menu untuk mengakhiri penggunaan terhadap aplikasi. Terdapat dua pilihan Ya atau Tidak jika ingin mengakhiri aplikasi pilih button Ya, jika tidak pilih button Tidak.

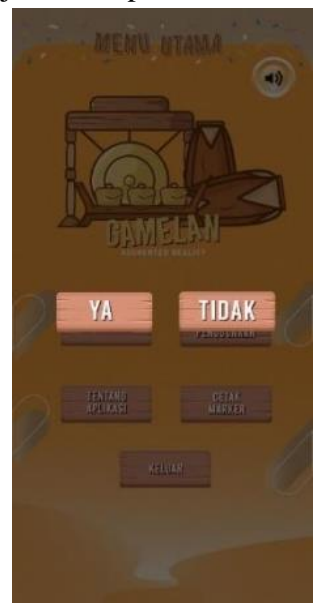

Gambar 4.5 Tampilan Halaman Tentang Aplikasi (Sumber : karya penulis)

\subsection{Pengujian Sistem}

Tahap ini merupakan tahap uji coba memasang dan menjalankan aplikasi yang sudah dibangun kedalam smartphone Android. Uji coba aplikasi interaktif ini telah dilakukan di empat perangkat smartphone Android dengan versi sistem operasi yang sama. Apabila ada masalah pada aplikasi tersebut akan dilakukan perbaikan (trial and error) hingga aplikasi dapat dijalankan dan berfungsi sebagai mestinya. Berikut adalah spesifikasi perangkat yang penulis gunakan untuk uji coba aplikasi: 
Tabel 4.1 Spesifikasi Perangkat Smartphone

\begin{tabular}{|c|c|c|c|c|c|}
\hline \multirow{2}{*}{$\begin{array}{c}\text { Perangka } \\
\text { t } \\
\text { Smartph } \\
\text { one } \\
\text { Android }\end{array}$} & \multicolumn{5}{|c|}{ Spesifikasi } \\
\hline & $\begin{array}{c}\text { Processo } \\
\mathrm{r}\end{array}$ & $\begin{array}{c}\text { RA } \\
\text { M }\end{array}$ & $\begin{array}{c}\text { Resolusi } \\
\text { Kamera }\end{array}$ & $\begin{array}{c}\text { Resol } \\
\text { usi } \\
\text { Layar }\end{array}$ & $\begin{array}{c}\text { OS } \\
\text { Andro } \\
\text { id } \\
\end{array}$ \\
\hline $\begin{array}{c}\text { Perangka } \\
\text { t } 1 \\
\text { (Xiaomi } \\
\text { Redmi } \\
\text { Note 5) }\end{array}$ & $\begin{array}{l}\text { Qualcom } \\
\text { Snapdrag } \\
\text { on } 636\end{array}$ & $\begin{array}{c}4 \\
\text { GB }\end{array}$ & $\begin{array}{l}15 \mathrm{MP}+5 \\
\mathrm{MP} \text { Dual } \\
\text { Kamera }\end{array}$ & $\begin{array}{c}2160 \\
\mathrm{x} \\
1080 \\
\text { pixels }\end{array}$ & $\begin{array}{l}\text { Andro } \\
\text { id Pie } \\
9.0\end{array}$ \\
\hline $\begin{array}{c}\text { Perangka } \\
\text { t } 2 \\
\text { (Xiaomi } \\
\text { Redmi } \\
\text { Note } 8 \text { ) }\end{array}$ & $\begin{array}{l}\text { Qualcom } \\
\text { Snapdrag } \\
\text { on } 665\end{array}$ & $\begin{array}{c}3 \\
\text { GB }\end{array}$ & $\begin{array}{c}\text { Quad } \\
\text { Camera } \\
48 \mathrm{MP}\end{array}$ & $\begin{array}{c}2340 \\
\mathrm{x} \\
1080 \\
\text { pixels }\end{array}$ & $\begin{array}{l}\text { Andro } \\
\text { id } \\
\text { Queen } \\
\text { Cake } \\
10 \\
\end{array}$ \\
\hline $\begin{array}{c}\text { Perangka } \\
\text { t } 3 \\
\text { (Samsun } \\
\text { g A51) }\end{array}$ & $\begin{array}{c}\text { Exynos } \\
9611\end{array}$ & $\begin{array}{c}6 \\
\text { GB }\end{array}$ & $\begin{array}{c}\text { Quad } \\
\text { Camera } \\
48 \mathrm{MP}\end{array}$ & $\begin{array}{c}2400 \\
\mathrm{X} \\
1080 \\
\text { pixels }\end{array}$ & $\begin{array}{l}\text { Andro } \\
\text { id Red } \\
\text { Velve } \\
\text { t } 11\end{array}$ \\
\hline $\begin{array}{c}\text { Perangka } \\
\text { t } 4 \\
\text { (Sony } \\
\text { Xperia } \\
\text { xz) } \\
\end{array}$ & $\begin{array}{l}\text { Qualcom } \\
\text { Snapdrag } \\
\text { on } 820\end{array}$ & $\begin{array}{c}3 \\
\text { GB }\end{array}$ & $23 \mathrm{MP}$ & $\begin{array}{c}1920 \\
\mathrm{X} \\
1080 \\
\text { pixels }\end{array}$ & $\begin{array}{l}\text { Andro } \\
\text { id } \\
\text { Noug } \\
\text { at } 7.0\end{array}$ \\
\hline
\end{tabular}

Setelah seluruh perangkat telah disiapkan, kemudian dilakukan instalasi aplikasi pada masing-masing perangkat. Setelah proses instalasi selesai, lalu akan dilakukan pengujian berdasarkan kecepatan aplikasi berdasarkan waktu/detik pada saat aplikasi dijalankan. Mulai dari masuk ke fitur Augmented Reality, mendeteksi marker dan menampilkan objek, menampilkan video di youtube, menampilkan petunjuk penggunaan, menampilkan tentang aplikasi dan kembali ke menu utama. Berikut adalah hasil uji coba aplikasi pada empat perangkat Android.

Tabel 4.2 Pengujian Sistem Pada Smartphone

\begin{tabular}{|l|c|c|c|c|}
\hline \multicolumn{1}{|c|}{$\begin{array}{c}\text { Proses } \\
\text { Operasi } \\
\text { Aplikasi }\end{array}$} & $\begin{array}{c}\text { Perangka } \\
\mathrm{t} 1\end{array}$ & $\begin{array}{c}\text { Peringka } \\
\mathrm{t} 2\end{array}$ & $\begin{array}{c}\text { Peringka } \\
\mathrm{t} 3\end{array}$ & $\begin{array}{c}\text { Perangka } \\
\mathrm{t} \mathrm{4}\end{array}$ \\
\hline $\begin{array}{l}\text { Masuk ke } \\
\text { Menu } \\
\text { Utama }\end{array}$ & $15 \mathrm{~s}$ & $15 \mathrm{~s}$ & $15 \mathrm{~s}$ & $16 \mathrm{~s}$ \\
\hline $\begin{array}{l}\text { Masuk ke } \\
\text { Menu AR } \\
\text { Kamera }\end{array}$ & $4 \mathrm{~s}$ & $3 \mathrm{~s}$ & $3 \mathrm{~s}$ & $3 \mathrm{~s}$ \\
\hline $\begin{array}{l}\text { Deteksi } \\
\text { Marker dan } \\
\text { menampilka } \\
\mathrm{n} \text { objek }\end{array}$ & $1 \mathrm{~s}$ & $1 \mathrm{~s}$ & $1 \mathrm{~s}$ & $2 \mathrm{~s}$ \\
\hline $\begin{array}{l}\text { Menampilka } \\
\mathrm{n} \text { Video di } \\
\text { youtube }\end{array}$ & $2 \mathrm{~s}$ & $2 \mathrm{~s}$ & $1 \mathrm{~s}$ & $2 \mathrm{~s}$ \\
\hline $\begin{array}{l}\text { Menampilka } \\
\mathrm{n} \text { Petunjuk } \\
\text { Penggunaan }\end{array}$ & $1 \mathrm{~s}$ & $1 \mathrm{~s}$ & $1 \mathrm{~s}$ & $1 \mathrm{~s}$ \\
\hline $\begin{array}{l}\text { Menampilka } \\
\mathrm{n} \text { Tentang } \\
\text { Aplikasi }\end{array}$ & $1 \mathrm{~s}$ & $1 \mathrm{~s}$ & $1 \mathrm{~s}$ & $1 \mathrm{~s}$ \\
\hline $\begin{array}{l}\text { Kembali Ke } \\
\text { menu utama }\end{array}$ & $1 \mathrm{~s}$ & $1 \mathrm{~s}$ & $1 \mathrm{~s}$ & $1 \mathrm{~s}$ \\
\hline
\end{tabular}

Berdasarkan hasil dari pengujian aplikasi pada perangkat Android, maka aplikasi AR Gamelan dapat berjalan dengan baik pada semua perangkat. Hal ini didukung dengan standar processor yang sesuai. Satu dari empat perangkat mengalami delay pada saat mendeteksi marker dan menampilkan objek dan delay ketika membuka aplikasi sampai ke menu utama, Serta pada semua perangkat mengalami stretch karena default dari resolusi layar yang digunakan penulis adalah layar pada smartphone berukuran 18:9 ratio. Dapat disimpulkan bahwa standar spesifikasi smartphone yang sesuai dengan standar yang telah disarankan juga mempengaruhi berjalan atau tidaknya aplikasi ini serta berfungsinya semua fitur yang telah diharapkan oleh penulis. Aplikasi ini dapat berjalan dengan semestinya pada resolusi layar 18:9 2160 x 1080 pixels.

\subsection{Pengujian Aplikasi Terhadap Responden}

Ini merupakan pengujian terhadap user atau pengguna untuk mengetahui respon pengguna terhadap aplikasi. Tahap ini dilakukan dengan membagikan kuisioner kepada para anggota grup Komunitas Gamelan anak muda jabodetabek atau SALgamelan (Samurti Andaru Laras). Dengan kuisioner ini dapat diketahui apakah aplikasi ini sudah memenuhi tujuan dari pembuatan aplikasi ini sebagai media yang dapat meningkatkan minat anak muda dalam mengenal alat musik gamelan jawa.

Dari hasil pengujian, implementasi aplikasi dan hasil jawaban kuisioner diketahui kondisinya adalah sebagai berikut:

Tabel 4.3 Hasil Pengujian Aplikasi Dengan Metode Kuisioner

\begin{tabular}{|c|c|c|c|c|c|}
\hline \multirow{2}{*}{ NO } & \multirow{2}{*}{ Pernyataan } & \multicolumn{4}{|c|}{ Pilihan } \\
\hline & & SS & $\mathrm{S}$ & $\mathrm{KS}$ & TS \\
\hline 1 & $\begin{array}{l}\text { Tampilan aplikasi ini menarik } \\
\text { dan mudah dipahami }\end{array}$ & 13 & 14 & 2 & 1 \\
\hline 2 & $\begin{array}{l}\text { Bentuk alat musik gamelan yang } \\
\text { ditampilkan sudah sesuai }\end{array}$ & 18 & 12 & & \\
\hline 3 & $\begin{array}{l}\text { Suara atau audio dari masing- } \\
\text { masing alat musik gamelan } \\
\text { terdengar jelas }\end{array}$ & 16 & 12 & 1 & 1 \\
\hline 4 & $\begin{array}{l}\text { Informasi yang ditampilkan } \\
\text { sudah informatif }\end{array}$ & 13 & 15 & 2 & \\
\hline 5 & $\begin{array}{l}\text { Aplikasi ini dapat membantu } \\
\text { menambah minat dalam } \\
\text { mempelajari alat musik gamelan }\end{array}$ & 18 & 11 & 1 & \\
\hline & Jumlah Skor & 78 & 64 & 6 & 2 \\
\hline
\end{tabular}

Keterangan Pilihan :

SS $\quad$ : Sangat Setuju

S : Setuju

KS : Kurang Setuju

TS : Tidak Setuju 
Jumlah responden adalah 30 orang dengan jumlah pernyataan sebanyak lima pernyataan maka total skor adalah 150. Dari tabel kuisioner diatas jumlah skor jawaban yang menyatakan sangat setuju adalah 78 , setuju 64 , kurang setuju 6, tidak setuju 2. Dari jumlah skor jawaban diperoleh dari para responden, maka presentase yang didapat sebagai berikut:

$$
\begin{array}{ll}
\text { SS }(\text { Sangat Setuju) } & : 78 / 150 \times 100 \%=52 \% \\
S \quad(\text { Setuju }) & : 64 / 150 \times 100 \%=42,7 \% \\
\text { KS (Kurang Setuju) }: 6 / 150 \times 100 \%=0,4 \% \\
\text { TS (Tidak Setuju) }: 2 / 150 \times 100 \%=0,13 \%
\end{array}
$$

Dari hasil presentase, responden yang menyatakan sangat setuju sebanyak $52 \%$, setuju sebanyak $42,7 \%$, kurang setuju sebanyak $0,4 \%$, dan tidak setuju sebanyak $0,13 \%$. Langkah terakhir yaitu menentukan nilai efektif keseluruhan dari presentase skor yang diperoleh. Jika skor dibawah atau kurang dari 50\% maka dapat dikatakan kurang efektif, sebaliknya jika lebih dari 50\% maka bisa dikatakan efektif. Rata-rata tertinggi adalah penyataan sangat setuju yakni $52 \%$. Maka aplikasi ini dapat disimpulkan bahwa aplikasi ini sudah sesuai dengan tujuan penulis yaitu sebagai media pengenalan untuk meningkatkan minat kepada anak muda terhadap Gamelan jawa.

\section{KESIMPULAN DAN SARAN}

\subsection{Simpulan}

Pada pembuatan Augmented Reality mengenai alat musik Gamelan Jawa berbasis Android ini terdapat beberapa simpulan, yaitu. Penulis telah menyelesaikan perancangan dan pembuatan aplikasi Augmented Reality pada perangkat mobile android sebagai media pengenalan alat musik Gamelan Jawa. Aplikasi ini dapat menampilkan objek 3D Gamelan Jawa dan dapat menampilkan audio disetiap alat musiknya yang dimana dalam pengujiannya aplikasi ini dapat berjalan dengan semestinya di smartphone berbasis android dengan spesifkasi sistem operasi minimum android 4.1 atau jelly bean. Dengan adanya booklet yang dipadukan dengan teknologi Augmented Reality pembaca akan lebih memahami dalam mencerna informasi yang disediakan. Serta Aplikasi ini dapat menambah minat anak muda akan ketertarikan untuk mengetahui alat musik Gamelan jawa.

\subsection{Saran}

Beberapa hal yang dapat dikembangkan dari aplikasi Augmented Reality Pengenalan Alat musik Gamelan Jawa, Adapun saran dari penulis kepada pembaca yang mungkin akan membuat karya serupa dengan penulis berikut beberapa saran yang disampaikan oleh penulis:

1. Aplikasi ARGamelan ini masih dapat dikembangkan lagi dengan dilengkapi animasi pada setiap alat musik yang lebih menarik.

2. Informasi yang disajikan dapat ditambahkan dan dikembangkan lagi, sehingga lebih lengkap dan akurat.
3. Objek 3D pada aplikasi ini masih dapat dikembangkan dan ditambah lebih banyak objek alat musik mengenai gamelan.

4. Penambahan lagu atau gending karawitan pada fitur di aplikasi.

\section{DAFTAR PUSTAKA}

[1] Ardiansyah, M. R. (2020). Pembuatan Aplikasi Augmented Reality Sebagai Media Informasi Mengenai Kampung Kreatif Tematik Pada Smart Branding Kota Bogor Berbasis Android, Jakarta: Politeknik Negeri Media Kreatif Jakarta.

[2] Firdaus, M., Yonia, D.L. (2017). Aplikasi 3D Alat Musik Tradisional Berbasis Augmented Reality : Program Studi Teknik Informatika Universitas 17 Agustus 1945 Surabaya.

[3] Iswara, N.H. Dinamika Kesenian Gamelan Pada Fungsi dan Pelestarian Kesenian Gamelan dalam Sanggar Budaya Singhasari di Kecamatan Singosari, Kabupaten Malang, Jawa Timur. Oase Cakrawala

[4] Milgram, P., Kishino, F. Augmented Reality: A Class of Displays on the Reality virtuality Continuum. In: SPIE Proceeding Telemanipulator and Telepresence Technologies, vol. 2351. 1994.

[5] Mustaqim, I. (2016). Pemanfaatan Augmented Reality Sebagai Media Pembelajaran. Jurnal Pendidikan Teknologi dan Kejuruan, Vol.13,No.2, Hal:174 ISSN 2521-0652.

[6] Safaat H.N. (2012). Pemrograman Aplikasi Mobile Smartphone Dan Tablet PC Berbais Android.

[7] Sofiudin,M., Khriza, T.M., Widarti, D.W. (2019). Aplikasi Pembelajaran Berbasis Augmented Reality Pada Buku Pengenalan Alat Musik Modern Untuk Anak. Jurnal Teknika Volume 11, No.1, 2019, ISSN: 2085-0859.

[8] Tribun Jogja (2018) SD Joannes Bosco Kembangkan Kearifan Lokal melalui Muatan Lokal Karawitan. Diakses dari URL : https://jogja.tribunnews.com/2018/02/28/sdjoannes-bosco-kembangkan-kearifan-lokal-melalui- muatanlokal-karawitan?page $=3$

[9] Yoga, R. A. (2019). Pembuatan Aplikasi Augmented Reality Sebagai Media Informasi Mengenai Smart Branding Pada Smart City Kota Bogor Berbasis Android. Jakarta: Politeknik Negeri Media Kreatif Jakarta.

[10] Yoga, R. A. (2019). Pembuatan Aplikasi Augmented Reality Sebagai Media Informasi Mengenai Smart Branding Pada Smart City Kota Bogor Berbasis Android. Jakarta: Politeknik Negeri Media Kreatif Jakarta. 


\section{BIODATA PENULIS}

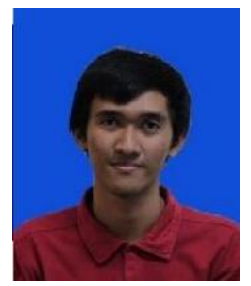

Ahmad Triaji

Lahir di Jakarta, 09 April 2000. Mahasiswa

Politeknik Negeri Media Kreatif Jakarta,

Program Studi Multimedia, Tempat tinggal

di Depok, Memiliki Hobi Olahraga Futsal. 
